\title{
Editorial
}

\section{Henco Bekkering}

Emeritus Professor of Urban Design, Faculty of Architecture and the Built Environment, Delft University of Technology, Delft, the Netherlands

\section{Hendrik Tieben}

Director MSc in Urban Design, School of Architecture, The Chinese

University of Hong Kong, Hong Kong, P. R. China
The idea for the double themed issue on urban design for an inclusive economy originated during the preparation for the tenth conference of the International Forum on Urbanism (IFoU) at the Chinese University of Hong Kong: 'The Entrepreneurial City'. In a wide range of contributions the participants discussed how key aims of UN Habitat's 'New Urban Agenda' could be implemented, and in particular how the fields of urban design and planning could contribute in creating a more inclusive economy and a more broadly shared urban prosperity. Part I of this themed issue was published in 2018 and included four papers (Bekkering and Tieben, 2018).

This second issue has three more papers. The first deals with the research of urban form in the context of economic changes on the metropolitan and central city scales, the second concentrates on the development and spread of self-employment on the scale of a large urban district and the third investigates the role played by housing types on the neighbourhood scale. The first investigates the fast growing city of Wuhan, China, the second the rapidly transforming Thamesmead, UK and the third highlights transforming poor neighbourhoods in Mumbai, India. All three make use of mapping as a research tool and/or explanatory device, each in its own way. These three papers - together with the four papers in part I - show very different ways in which urban design, and the thinking behind it, can and does influence economic opportunities. As in the first issue, the papers in this second issue are inevitably multi-disciplinary in their approaches. The first combines urban studies with history, the second with ethnography and the third with economy. There are of course many more ways in which urban design influences economic opportunities, as evidenced by the proceedings of the conference 'The Entrepreneurial City' mentioned previously (Tieben et al., 2018). The editors regard the three papers presented here to be very relevant to the theme.

The first paper, by Bekkering et al. (2019), presents the partial results of a historical morphological research detecting the transformations in the urban form of the Chinese mediumsized industrial city of Wuhan. A great many historical maps were available, quite unusual for a Chinese city. This allowed the research to go back to 1870 when what is now a metropolis consisted of three small towns. The contemporary city with over 12 million inhabitants is located centrally in China and, according to national planning, is transforming from a monofunctional to a multifunctional economy, while retaining its basic industries based on steel manufacturing. This aspect allows for a comparison with Detroit, USA, the urban form of which was researched in a similar way by the first author a few years earlier (Bekkering and Liu, 2015). 'There are certain parallels between the economic and urban development of the two cities, though also great differences based largely on their national political contexts' (Bekkering et al., 2019: p. 47). The research uses the method of the Delft School of morphological analysis, applying the reductive mapping technique of defining homogeneous areas, intended to select map information explicitly so as to show the permanency and the transformation of formal structure through time.

The second paper, by Uliarte et al. (2019), explores employment trends in a London district that historically houses low-income communities. The research shows how many selfemployed residents run 'invisble' businesses, both from their homes and from communal facilities offering help in a variety of ways and a network of peers. The authors state

\footnotetext{
Through mapping, census data analysis and semi-structured interviews with local 'invisible'-business owners, the research focused on understanding these businesses and reveals and explores three key characteristics of the interactions with the urban landscape of Thamesmead. First, census data reveal a shift in the area's demographics over the past two decades. These shifts include the largest account of African immigration, rising levels of education and a growing number of self-employed residents and small businesses. Second, the research showed a disconnect between infrastructure and the community it is meant to serve. Local business owners lack knowledge, awareness and accessibility to existing supportive local institutions and social infrastructure. Third, the paper examines the above-stated characteristics in the context of the urban form. (Uliarte et al., 2019: p. 61)
}

Based on the lack of more appropriate or affordable spaces, important tools to run these 'invisible' businesses have become social media and the internet. Consequently, their mapping required additional layers identifying locations of these online businesses in the urban form. 
The third paper, by Khandhar and Khandhar (2019), investigates the role played by housing - type and context - in the livelihood strategies of the urban poor in several neighbourhoods in Mumbai, India. The authors write that the paper 'makes two main arguments, namely that the urban house is an entrepreneurial resource which the urban poor use as a mode of income generation and that such housing has specific attributes, which are brought about by the action of certain mechanisms that need to be investigated' (Khandhar and Khandhar, 2019: p. 70). As a result of changing production and consumption patterns, the manufacturing sector is giving way to the service sector, and the authors see 'the emergence of a new structure of the city as a city of entrepreneur agents' (Khandhar and Khandhar, 2019: p. 71). This results in the need for new housing types, in the end influencing the urban landscape of the whole metropolis.

\section{REFERENCES}

Bekkering HC and Liu Y (2015) Mapping Detroit: "The City of Holes". In Mapping Detroit. Land, Community, and Shaping a City
(Thomas JM and Bekkering HC (eds.)). Wayne State University Press, Detroit, MI, USA, pp. 27-50.

Bekkering $\mathrm{H}$ and Tieben $\mathrm{H}$ (2018) Editorial. Proceedings of the Institution of Civil Engineers - Urban Design and Planning 171(6): 229-230, https://doi.org/10.1680/ jurdp.2018.171.6.229.

Bekkering HC, Cai J and Kuijper J (2019) Mapping Wuhan: historical morphological research. Proceedings of the Institution of Civil Engineers - Urban Design and Planning 172(2): 47-60, https://doi.org/10.1680/jurdp.18.00033.

Khandhar SB and Khandhar JS (2019) Beyond shelter: the urban house as an entrepreneurial resource. Proceedings of the Institution of Civil Engineers - Urban Design and Planning 172(2): 71-81, https://doi.org/10.1680/jurdp.18.00042.

Tieben H, Geng Y and Rossini F (eds) (2018) The Entrepreneurial City. Tenth Conference of the International Forum on Urbanism (IFoU). The International Forum on Urbanism, Rotterdam, the Netherlands and The Chinese University of Hong Kong, Hong Kong, P. R. China.

Uliarte IP, Ackeifi B, Faria JC, Mansour G and Tovatt O (2019) Mapping Thamesmead's invisible economies: an ethnographic approach to self-employment. Proceedings of the Institution of Civil Engineers - Urban Design and Planning 172(2): 61-70, https://doi.org/10.1680/ jurdp. 18.00030 . 